\title{
PERSEPSI MAHASISWA TERHADAP PELAKSANAAN PERKULIAHAN EKSPERIMEN JARAK JAUH FISIKA DASAR DI MASA PANDEMI
}

\author{
Dina Syaflita ${ }^{1}$, Naila Fauza ${ }^{2}$, Zulhelmi $^{3}$, Ernidawati $^{4}$ \\ Pendidikan Fisika, Universitas Riau ${ }^{1,2,3,4}$ \\ Email: dina@lecturer.unri.ac.id
}

\begin{abstract}
Abstrak
Pelaksanaan eksperimen fisika dasar jarak jauh di masa pandemi memiliki tantangan tersendiri. Eksperimen ini memiliki kendala baik dalam hal perencanaan, pelaksanaan, dan pelaporan. Tujuan penelitian ini adalah untuk mendeskripsikan pelaksanaan eksperimen fisika dasar jarak jauh secara sinkronous menggunakan alat sederhana serta mengetahui persepsi mahasiswa terkait kendala dalam pelaksanaan pembelajaran eksperimen nyata jarak jauh secara sinkronous. Penelitian ini merupakan penelitian deskriptif kualitatif. Instrumen yang digunakan adalah angket yang disebar menggunakan Google Form. Responden dalam penelitian ini adalah 69 orang mahasiswa yang mengambil mata kuliah eksperimen fisika dasar semester ganjil tahun akademik 2020/2021. Analisis data penelitian dilakukan menggunakan metode analisis deskriptif. Hasil penelitian ini menunjukkan bahwa penerapan eksperimen berbantukan Google Meet menggunakan alat dan bahan sederhana yang mudah didapat oleh mahasiswa dapat mengurangi permasalahan melengkapi alat dan bahan oleh mahasiswa serta penggunaan Google Meet memungkinkan proses pendampingan selama eksperimen berlangsung oleh dosen pengampu. Kendala yang paling banyak ditemui oleh mahasiswa adalah kendala dalam tahap pelaksanaan dimana terkadang jaringan internet tidak mendukung sedangkan mahasiswa perlu mendengar arahan dosen pengampu terutama bila instruksi pada buku panduan kurang bisa dipahami.
\end{abstract}

Kata Kunci : Persepsi, Eksperimen Jarak Jauh, Fisika Dasar

\begin{abstract}
The implementation of remote basic physics experiments during a pandemic has its own challenges. This experiment had problems in terms of planning, implementation, and reporting. The purpose of this study are to describe the implementation of synchronous distance learning of fundamental physics experiments using simple tools and to find out students' perceptions regarding the obstacles in the synchronous distance learning implementation of experiments. This research is a qualitative descriptive study. The instrument used is a questionnaire distributed using Google Form. The respondents in this study were 69 students who took the fundamental physics experiment course in the odd semester of the 2020/2021 academic year. Analysis of research data was carried out using descriptive analysis methods. The results of this study indicated that the application of Google Meetassisted experiments using simple tools and materials that were easily obtained by students could reduce the problem of completing tools and materials by students and the use of Google Meet allowed the mentoring process during the experiment by the lecturer. The most common obstacles encountered by students were obstacles in the implementation phase where sometimes the internet network did not support it while students needed to listen to the direction of the supporting lecturer, especially if the instructions in the manual were not well understood.
\end{abstract}

Key Words : Perception, Long-distance Eksperiment, Fundamental Physics

\section{PENDAHULUAN}

Kebijakan pemerintah terkait upaya meminimalisir penyebaran virus Corona melalui social distancing, physical distancing, PSBB, hingga isolasi berdampak pada kebijakan dalam bidang pendidikan ([1], [2]). Wabah Covid-19 menuntut terjadinya perubahan pola pembelajaran dari tatap muka konvensional menjadi pembelajaran jarak jauh dari rumah yang dikenal dengan School from Home (SFH) atau bagi pendidik dikenal dengan Work from Home (WFH) [3]. Semua jenjang pendidikan 
harus beradaptasi untuk melaksanakan pembelajaran secara online [4]. Upaya ini dinilai mampu mengatasi permasalahan keterlambatan memperoleh ilmu pengetahuan oleh peserta didik meskipun sekolah telah ditutup [2]. Pembelajaran online dan/atau jenis jarak jauh lainnya menjadi alternatif solusi yang mungkin bagi pelaksanaan pembelajaran di masa pandemi.

Pembelajaran online adalah pembelajaran yang mengintegrasikan koneksi internet di dalamnya [5]. Pembelajaran online juga dapat diartikan sebagai proses pembelajaran di sekolah maya melalui penerapan teknologi informasi [6]. Pada dasarnya pembelajaran online merupakan pembelajaran jarak jauh. Pembelajaran ini dilakukan melalui jaringan internet, sehingga disebut juga dengan pembelajaran dalam jaringan (daring) [7].

Pembelajaran online atau pembelajaran jarak jauh dilaksanakan di masa pandemi berdasarkan Surat Edaran Menteri Pendidikan dan Kebudayaan Republik Indonesia Nomor 4 Tahun 2020 tentang Pelaksanaan Kebijakan Pemerintah dalam Masa Darurat Penyebaran Covid [8]. Pembelajaran di masa ini menuntut dunia pendidikan terbiasa menggunakan teknologi untuk pembelajaran online. Pembelajaran online menurut [7] tidak hanya sekedar membagikan materi pembelajaran dalam jaringan internet saja, tetapi ada proses pembelajaran yang terjadi disana yang pada akhirnya menciptakan pengalaman belajar. Dengan demikian, pembelajaran online tetap mengacu pada capaian tujuan pembelajaran sebagaimana kelas tatap muka konvensional hanya saja dilaksanakan dalam interaksi online. Salah satu kelas online adalah kelas virtual dalam bentuk konferensi.

Pembelajaran online memiliki keunggulan dan kelemahan. Keunggulan pembelajaran online dalam penelitian [9] adalah dari segi fleksibilitas penggunaan. Penelitian ini juga menemukan bahwa mahasiswa lebih nyaman mengemukakan pendapat pada forum pembelajaran online. Sedangkan tantangannya berkaitan dengan kesediaan dan kualitas jaringan internet, biaya, dan kemandirian belajar peserta didiknya. Karakteristik pembelajaran, tujuan yang ingin dicapai, dukungan fasilitas, dan kondisi siswa menjadi faktor penentu keunggulan dan tantangan yang dialami dalam suatu pembelajaran online.

Eksperimen merupakan salah satu pembelajaran terkait dengan membuktikan atau menemukan suatu fenomena. Eksperimen bertujuan untuk membuktikan sendiri apa yang sedang dipelajari [10]. Pembelajaran eksperimen Fisika Dasar pada dasarnya merupakan pembelajaran yang sarat akan kegiatan membuktikan hukum atau konsep fisika. Pembelajaran ini lebih sering dilakukan di laboratorium pada kelas tatap muka konvensional. Konsep-konsep dan hukum yang dibuktikan dalam eksperimen fisika dasar meliputi konsep dan hukum materi fisika seperti pengukuran, kinematika, dinamika, suhu dan kalor, gelombang, kelistrikan, dan kemagnetan.

Pembelajaran eksperimen yang mestinya dilakukan di laboratorium dengan fasilitas yang memadai mungkin terlaksana pada pembelajaran tatap muka konvensional. Namun, pada pembelajaran eksperimen jarak jauh hal itu tidak dapat dilakukan. Pelaksanaan eksperimen di masa pandemi disiasati dengan berbagai strategi. Hasil penelitian menunjukkan bahwa mayoritas pelaksanaan eksperimen di masa pandemi dilakukan dengan eksperimen menggunakan alat dan bahan sederhana [11]. Selain itu, eksperimen juga dilaksanakan dengan cara penugasan melalui pembuatan video, memanfaatkan aplikasi online untuk eksperimen virtual, 
penjelasan video dari sumber online, dan penjelasan video yang dibuat sendiri oleh guru/dosen.

Eksperimen perkuliahan Fisika Dasar Prodi Pendidikan Fisika Universitas Riau di masa pandemi dilakukan dengan menggunakan metode eksperimen jarak jauh dimana mahasiswa melaksanakan eksperimen di rumah masing-masing menggunakan alat dan bahan sederhana. Eksperimen jarak jauh menggunakan alat dan bahan sederhana merupakan upaya untuk mengurangi masalah ketersediaan alat dan bahan eksperimen [12]. Pelaksanaan eksperimen ini dilaksanakan dengan sistem online sinkronous menggunakan Google Meet, sehingga pelaksanaan eksperimen ini dapat dipantau oleh dosen pengampu. Meskipun demikian, pandangan peserta didik terhadap pembelajaran eksperimen menggunakan alat sederhana secara sinkronous ini perlu dilakukan sehingga dapat dijadikan acuan dan bahan pertimbangan bagi guru/dosen yang ingin melaksanakan eksperimen seperti ini pada semester-semester berikutnya. Tujuan penelitian ini adalah untuk mendeskripsikan pelaksanaan eksperimen fisika dasar jarak jauh secara sinkronous menggunakan alat sederhana serta mengetahui persepsi mahasiswa terkait kendala dalam pelaksanaan pembelajaran eksperimen nyata jarak jauh secara sinkronous. Adapun manfaat penelitian ini adalah sebagai informasi bagi pendidik terkait kendala yang mungkin dihadapi apabila melaksanakan eksperimen nyata jarak jauh secara sinkronous, sehingga informasi ini dapat menjadi bahan pertimbangan nantinya.

\section{METODE}

Penelitian ini merupakan penelitian deskriptif kualitatif dimana penelitian ini ditujukan untuk mendeskripsikan dan menggambarkan mengenai pelaksanaan perkuliahan eksperimen jarak jauh secara online dengan memanfaatkan Google Meet di masa pandemi. Pelaksanaan eksperimen dilaksanakan di rumah masing-masing menggunakan alat eksperimen sederhana. Selama eksperimen berlangsung, dosen dan mahasiswa bertatap muka secara virtual menggunakan Google Meet. Eksperimen ini dilakukan sebanyak tujuh kali dengan judul eksperimen yang berbeda.

Instrumen yang digunakan adalah angket yang disebar menggunakan Google Form. Indikator angket yang disebar berisi aspek berikut: 1) Kendala jaringan, pada angket indikator dibuat dalam bentuk pertanyaan apakah masalah jaringan menjadi masalah yang cukup mempengaruhi pelaksanaan perkuliahan eksperimen fisika dasar di masa pandemi dan tuliskan masalah jaringan yang cukup mempengaruhi pelaksanaan perkuliahan eksperimen fisika dasar yang dialami oleh mahasiswa; 2) Kendala di luar jaringan yang paling sering dihadapi mahasiswa baik dalam hal mempersiapkan alat dan bahan, pelaksanaan percobaan, dan pembuatan laporan hasil percobaan; dan 3) Pendapat mahasiswa terhadap keseluruhan proses pelaksanaan perkuliahan eksperimen fisika dasar secara sinkronous menggunakan alat dan bahan sederhana.

Responden dalam penelitian ini adalah sebanyak 69 orang mahasiswa yang sedang mengambil mata kuliah eksperimen fisika dasar semester ganjil tahun akademik 2020/2021. Analisis data penelitian dilakukan menggunakan metode analisis deskriptif.

\section{HASIL DAN PEMBAHASAN}

Pelaksanaan eksperimen fisika dasar sebagaimana halnya pelaksanaan eksperimen lainnya dilaksanakan dengan beberapa tahapan, yaitu tahap persiapan, pelaksanaan, dan pelaporan hasil 
eksperimen. Selama melaksanakan tahapan-tahapan ini terdapat beberapa kendala yang dihadapi oleh mahasiswa. Pada bagian ini dijelaskan bagaimana pelaksanaan dan kendala yang dihadapi mahasiswa selama melaksanakan persiapan, pelaksanaan, dan pelaporan hasil eksperimen.

Eksperimen jarak jauh secara online menggunakan alat-alat sederhana bertujuan untuk mengurangi masalah terkait alat dan bahan. Pelaksanaan yang dilaksanakan secara sinkronus bertujuan agar pelaksanaan eksperimen oleh mahasiswa dapat didampingi oleh dosen pengampu, sehingga masalah selama pelaksanaan eksperimen diharapkan dapat dikurangi. Eksperimen menggunakan alat-alat sederhana mudah dilaksanakan namun tidak mengurangi esensi tujuan eksperimen itu sendiri [11].

Kelancaran eksperimen jarak jauh secara online menggunakan Google Meet sangat bergantung pada kualitas jaringan internet. Hasil angket yang diisi oleh mahasiswa menunjukkan bahwa $84,1 \%$ mahasiswa mengalami masalah jaringan selama melaksanakan eksperimen yang dilaksanakan sebanyak tujuh kali tersebut. Sedangkan $15,9 \%$ nya menyatakan tidak mengalami masalah jaringan. Penelitian terkait pembelajaran di masa Covid-19 menunjukkan bahwa masalah jaringan merupakan faktor yang sangat mempengaruhi kualitas pembelajaran. Penelitian yang dilakukan menunjukkan bahwa kendala pembelajaran online umumnya adalah masalah kestabilan jaringan, suara guru dengan bahan ajar yang tidak serempak, dan tidak bisanya peserta didik mengambil kelas karena koneksi internet yang tidak memadai [13]. Selain itu, faktor ekonomi dan kesiapan teknologi merupakan faktor yang mempengaruhi kegiatan pembelajaran online [14]. Dapat ditarik kesimpulan bahwa keterbatasan kuota internet ([15], [16]), koneksi internet dan keterampilan ICT ([16], [17]) dapat menjadi faktor penghambat pencapaian efektivitas pembelajaran online.

Secara umum, kegiatan eksperimen dapat dikelompokkan menjadi tiga bagian yaitu tahap perencanaan, pelaksanaan, dan pelaporan hasil eksperimen. Setiap bagian memiliki kendala tersendiri. Pada bagian perencanaan, kendala yang dihadapi oleh sebagian besar mahasiswa adalah melengkapi alat dan bahan dan menemukan alat dan bahan yang 'memuaskan'. Beberapa percobaan terkadang membutuhkan alat yang harus dibuat terlebih dahulu untuk bisa digunakan dalam eksperimen. Selain itu, meskipun menggunakan alat dan bahan sederhana tetapi terkadang alat dan bahan yang mereka pilih hasilnya kurang memuaskan. Misalnya, untuk mengukur massa jenis benda mahasiswa membutuhkan neraca dan gelas ukur. Neraca yang mudah didapat mahasiswa memiliki skala terkecil rata-rata adalah 10 gram sedangkan untuk mengukur volume biasanya digunakan botol susu yang ada takaran volumenya. Penggunaan alat-alat dengan skala yang cukup besar ini memberikan hasil yang tidak terlalu teliti.

Proses pelaksanaan eksperimen dilaksanakan dengan menggunakan Google Meet. Mahasiswa membutuhkan arahan dan pemaparan dosen selama eksperimen bilamana ada yang tidak dimengerti. Masalah jaringan menjadi masalah utama pada saat pelaksanaan eksperimen seperti ini, karena mahasiswa membutuhkan arahan dan petunjuk dari dosen saat pelaksanaan eksperimen. Beberapa mahasiswa ada yang tidak berhasil karena tidak memahami dengan baik instruksi pada buku panduan eksperimen ditambah lagi dengan koneksi internet yang buruk yang menyebabkan mereka kesulitan 
mendengarkan instruksi dari dosen pengampu mata kuliah ini. Hal ini mempengaruhi efektivitas pencapaian tujuan perkuliahan. Pembelajaran online sinkronous (conference) memudahkan asistensi dalam eksperimen sehingga dengan adanya tatap muka virtual mahasiswa tetap dapat dipandu oleh dosen pengampu [18]. Meskipun demikian, Penelitian menunjukkan bahwa mahasiswa tetap lebih menyukai pembelajaran tatap muka konvensional dibandingkan tatap muka virtual ([19], [20], [21]).

Bagian terakhir adalah bagian pelaporan hasil penelitian. Kendala dalam tahap pelaporan adalah pencarian referensi yang relevan. Sebagian besar mahasiswa membutuhkan jaringan internet yang baik untuk dapat mencari dan memilih referensi yang dibutuhkan. Selain itu, kesulitan lain yang dihadapi mahasiswa dalam melaporkan hasil penelitian adalah menganalisis dan menginterpretasi data hasil penelitian. Sebenarnya, untuk bagian pelaporan ini kendala yang dialami mahasiswa tidak jauh berbeda dari kendala dalam pelaporan di kelas eksperimen konvensional. Adapun kendala yang paling banyak dihadapi oleh mahasiswa terkait proses eksperimen (perencanaan, pelaksanaan, dan pelaporan) dapat dilihat pada Gambar 1.

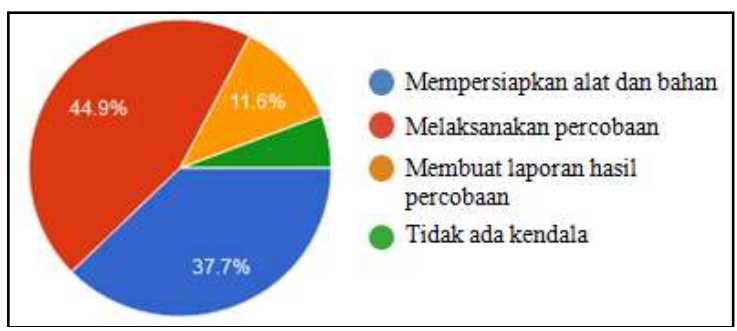

Gambar 1. Kendala yang Paling Banyak Ditemui Mahasiswa

Gambar 1 menunjukkan kendala yang paling banyak ditemui oleh mahasiswa selama pelaksanaan perkuliahan eksperimen jarak jauh fisika dasar di masa pandemi. Kendala yang paling banyak ditemui mahasiswa adalah pada saat melaksanakan eksperimen $(44,9 \%)$. Oleh karena eksperimen dilaksanakan dengan bantuan Google Meet, sehingga pelaksanaannya bergantung pada kualitas jaringan internet. Selama pelaksanaan, mahasiswa dapat bertanya mengenai pelaksanaan eksperimen. Dosen dapat melihat seperti apa eksperimen yang sedang dilakukan oleh mahasiswa apakah sudah sesuai dengan yang semestinya atau tidak. Meskipun demikian, pendampingan yang dilakukan secara online dinilai mahasiswa kurang cukup untuk membantu pelaksanaan eksperimen ini. Selain itu, Sebanyak 37,7\% mahasiswa kesulitan dalam melengkapi dan mendapatkan alat dan bahan yang sesuai untuk mendapatkan hasil eksperimen yang baik. 11,6\% mahasiswa terkendala pada saat membuat laporan eksperimen. Hanya 5,8\% mahasiswa yang merasa tidak mengalami kendala baik dalam hal perencanaan, pelaksanaan, maupun pelaporan hasil eksperimen.

Persepsi mahasiswa terhadap perkuliahan eksperimen online berbantukan Google Meet menggunakan alat dan bahan sederhana ditampilkan melalui Gambar 2.

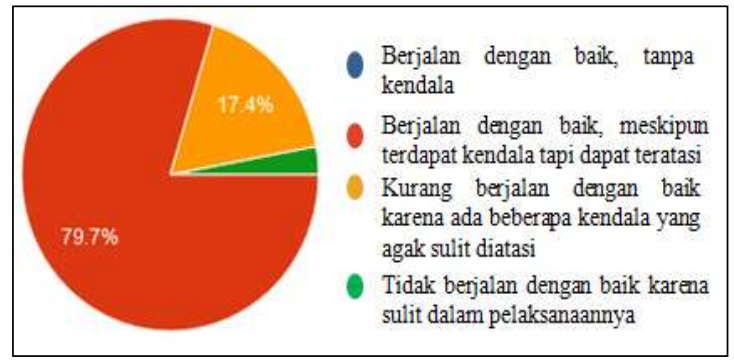

Gambar 2. Persepsi Mahasiswa terhadap Pelaksanaan Perkuliahan Eksperimen

Persepsi mahasiswa terkait perkuliahan eksperimen fisika dasar di masa pandemi yang berbeda dari eksperimen fisika dasar pada keadaan sebelumnya sangat diperlukan sebagai bahan pertimbangan dan pengambilan keputusan kedepannya. 
Gambar 2 menunjukkan bahwa sebanyak $79,7 \%$ mahasiswa menyatakan bahwa eksperimen fisika dasar yang dilaksanakan jarak jauh menggunakan Google Meet terlaksana dengan baik meskipun terdapat beberapa kendala tetapi dapat teratasi. Sebanyak 17,4\% mahasiswa menyatakan kurang berjalan dengan baik karena ada beberapa kendala yang agak sulit teratasi, dan 2,9\% menyatakan sulit dalam pelaksanaannya. Penelitian eksperimen sinkronus memanfaatkan YouTube dengan cara live menunjukkan bahwa eksperimen seperti ini memberikan hasil persepsi yang positif dari mahasiswa [22]. Penelitian juga menunjukkan bahwa sebelum penggunaan media yang memungkinkan dosen dan mahasiswa lebih leluasa untuk berinteraksi, lebih dari $50 \%$ responden menyatakan bahwa eksperimen online dirasa sulit [23].

\section{SIMPULAN}

Perkuliahan eksperimen jarak jauh fisika dasar secara sinkronous berbantukan Google Meet menggunakan alat dan bahan sederhana merupakan solusi pelaksanaan eksperimen di masa pandemi dimana mahasiswa dapat melaksanakan eksperimen di rumah masing-masing dengan alat dan bahan yang mudah didapat serta tetap didampingi oleh dosen pengampu mata kuliah. Pelaksanaan eksperimen ini menurut mahasiswa terlaksana dengan baik meskipun terdapat beberapa kendala namun tidak mempengaruhi. Kendala utama yang dihadapi oleh mahasiswa adalah kendala jaringan internet.

Kegiatan eksperimen terbagi dalam perencanaan, pelaksanan, dan pelaporan. Kendala pada tahap perencanaan adalah memperoleh alat dan bahan yang sesuai untuk mendapatkan hasil percobaan yang baik. Kendala pada saat pelaksanaan adalah masalah jaringan karena mahasiswa perlu didampingi saat eksperimen terutama ketika ada yang belum dipahami terkait instruksi pada buku panduan eksperimen. Kendala pada saat membuat laporan eksperimen adalah mencari referensi yang dibutuhkan dan mengolah serta menginterpretasi data.

\section{DAFTAR PUSTAKA}

[1] N. K. S. Astini, "Pemanfaatan Teknologi Informasi dalam Pembelajaran Tingkat Sekolah Dasar pada Masa Pandemi Covid-19," J. Lampuhyang, vol. 11, no. 2, pp. 1325, 2020.

[2] L. D. Herliandry, Nurhasanah, M. E. Suban, dan H. Kuswanto, "Pembelajaran pada Masa Pandemi Covid-19," J. Teknol. Pendidik., vol. 22, no. 1, pp. 65-70, 2020.

[3] H. Muhtarom, "Pemanfaatan Model Pembelajaran E-Learning dalam Pembelajaran Sosiologi Selama Masa Pandemi Covid-19," SAP (Susunan Artikel Pendidikan), vol. 5, no. 3, pp. 234-240, 2021.

[4] K. L. G. M. Z. Atsani, "Transformasi Media Pembelajaran pada Masa Pandemi Covid-19," Al-Hikmah J. Stud. Islam Vol., vol. 1, pp. 82-93, 2020.

[5] N. Adijaya dan L. P. Santosa, "Persepsi Mahasiswa dalam Pembelajaran Online," Wanastra J. Bhs. dan Sastra, vol. 10, no. 2, pp. 105-110, 2018.

[6] Basori, "Efektifitas Komunikasi Pembelajaran Online dengan Menggunakan Media E-Learning pada Perkuliahan Body Otomotif," JIPTEK, vol. 7, no. 2, pp. 39-45, 2014.

[7] T. Belawati, 2020, Pembelajaran Online, Banten: Universitas Terbuka.

[8] Surat Edaran Nomor 4 Tahun 2020 tentang Pelaksanaan Kebijakan Pendidikan dalam Masa Darurat Penyebaran Corona Virus Desease (Covid-19). Jakarta: Kemendikbud.

[8] Firman dan S. R. Rahman, 
"Pembelajaran Online di Tengah Pandemi Covid-19," Indones. J. Educ. Sci., vol. 02, no. 02, pp. 81-89, 2020

[10] M. G. Nugraha dan K. H. Kirana, "Profil Keterampilan Berpikir Kritis Mahasiswa Fisika Problem Solving," in Prosiding Seminar Nasional Fisika (E-Journal) SNF2015, vol. IV, pp. 201-204, 2015.

[11] A. F. Mardhotillah et al., "Studi Eksplorasi Kegiatan Praktikum Sains Saat Pandemi Covid-19," Indones. J. Sci. Learn., vol. 1, no. 2, pp. 67-75, 2020.

[12] P. Winarti, "Analisis Kesulitan Belajar Mahasiswa dalam Perkuliahan Konsep Dasar IPA Fisika Secara Daring di Masa Pandemi Covid-19," J. Komun. Pendidik., vol. 5, no. 1, pp. 93-107, 2021.

[13] L. Handayani, "Keuntungan, Kendala dan Solusi Pembelajaran Online Selama Pandemi Covid-19: Studi Ekploratif di SMPN 3 Bae Kudus Lina Handayani," J. Ind. Eng. Manag. Res. (JIEMAR), vol. 1, no. 2, pp. 15-23, 2020.

[14] B. D. C, A. Amelia, U. Hasanah, dan A. M. Putra, "Analisis Keefektifan Pembelajaran Online di Masa Pandemi Covid-19," Mahaguru J. Pendidik. Guru Sekol. Dasar, vol. 2, no. 1, pp. 28-37, 2020.

[15] A. Widodo and Nursaptini, "Problematika Pembelajaran Daring dalam Perspektif Mahasiswa," ELSE (Elementary School Education Journal), vol. 4, no. 2, pp. 100-115, 2020.

[16] D. Jamaluddin, T. Ratnasih, $H$. Gunawan, and E. Paujiah, "Pembelajaran Daring Masa Pandemik Covid-19 pada Calon Guru: Hambatan, Solusi dan Proyeksi," : Eurasia Journal of
Mathematics, Science and Technology Education, Vol. 16, No. 7, no. 1-9, 2020.

[17] Mailizar, A. Almanthari, S. Maulina, and S. Bruce, "Secondary School Mathematics Teachers' Views on ELearning Implementation Barriers during the COVID-19 Pandemic: The Case of Indonesia," Eurasia J. Math. Sci. Technol. Educ., vol. 16, no. 7, pp. 1-9, 2020.

[18] A. H. Rustaman, "Efektivitas Penggunaan Aplikasi Daring, Video Conference dan Sosial Media pada Mata Kuliah Komputer Grafis 1 di Masa Pandemi Covid-19," J. Ilmu Sos. dan Pendidik., vol. 4, no. 3, pp. 557-562, 2020.

[19] S. Ningsih, "Persepsi Mahasiswa terhadap Pembelajaran Daring pada Masa Pandemi Covid-19," Jinotep (Jurnal Inov. Teknol. Pembelajaran), vol. 7, no. 2, pp. 124-132, 2020.

[20] L. O. Anhusadar, "Persepsi Mahasiswa PIAUD terhadap Kuliah Online di Masa Pandemi," J. Islam. Early Child. Educ., vol. 3, no. 1, pp. 44-58, 2020.

[21] J. A. Dewantara dan T. H. Nurgiansah, "Efektivitas Pembelajaran Daring di Masa Pandemi Covid-19 bagi Mahasiswa Universitas PGRI Yogyakarta," $J$. basicedu, vol. 5, no. 1, pp. 367-375, 2021.

[22] Akhmad Al-Bari and R. K. Saputri, "Persepsi Mahasiswa terhadap Praktikum Daring Mata Kuliah Kimia Analisis," J. Educ. FKIP UNMA, vol. 6, no. 2, pp. 676-683, 2020.

[23] M. V. B. Halawa, "Efektivitas Pemanfaatan Platform Media Sosial dalam Pembelajaran Praktikum Secara Daring," Attract. Innov. Educ. J., vol. 3, no. 1, pp. 52-64, 2021. 